Ekonomia - Wroclaw Economic Review 26/4 (2020)

Acta Universitatis Wratislaviensis

No 4009

https://doi.org/10.19195/2658-1310.26.4.4

Rafał Krywienia

ORCID: 0000-0002-9615-3583

Uniwersytet Wrocławski

292751@uwr.edu.pl

\title{
Ocena funkcjonowania projektu e-zdrowie na rynku usług medycznych w świetle badań ankietowych
}

Artykuł nadesłany: 30.06.2020; artykuł zaakceptowany: 10.10.2020

Kody klasyfikacji JEL: I11, I18, I19

Keywords: e-health, telemedicine, healthcare

\begin{abstract}
Assessment of the e-health project functioning on the medical services market in the light of surveys

The idea of the e-health project assumes the public use of effective information and communication technology systems, as well as the participation of patients and medical staff in the treatment process. The article's aim is the analysis of the impact of the e-health project on the functioning of the Polish healthcare system which is currently implemented as part of the digitization of health care. It has been hypothesized that the implemented e-health project has been positively received by Polish society. In order to verify this, a survey was conducted on a sample of 305 respondents, including patients, doctors and people who had never had contact with e-health. The purpose of the survey was to recognize the attitudes, opinions and experience of beneficiaries of e-health regarding the functioning of the project in question. The article also contains secondary research presenting the current scientific achievements in the field of e-health.
\end{abstract}

\section{Wstęp}

W XXI wieku coraz bardziej popularne stają się technologie informacyjne i komunikacyjne. Przy zachowaniu postępu społecznego i technologicznego nieuniknione wydaje się zastosowanie nowoczesnych technologii w ramach narodowego systemu ochrony zdrowia. Celem niniejszego artykułu jest przedstawienie ogólnej idei systemu e-zdrowia, jego najważniejszych funkcji, a także dokonanie oce- 
ny funkcjonowania projektu e-zdrowia w Polsce. W tym celu autor przeprowadził badania pierwotne z zamierzeniem poznania postaw oraz doświadczeń beneficjentów, dotyczących funkcjonowania projektu e-zdrowie, a co za tym idzie opinii odnośnie do wprowadzonego systemu informatycznego. W artykule przedstawione zostały również badania wtórne odnoszące się do poruszonego tematu. Niewątpliwie stroną popytową rozwiązań w zakresie e-zdrowia może być każdy obywatel Polski, który wymaga opieki zdrowotnej zarówno publicznej służby zdrowia, jak i usług prywatnych firm medycznych. Na podstawie badania - kwestionariusza internetowego - przeprowadzonego na terenie całego kraju na przełomie kwietnia i maja 2020 roku na próbie 305 osób możemy poznać, w jakim stopniu Polacy są świadomi obecności projektu e-zdrowie oraz jak go oceniają. W formularzu znalazły się pytania zamknięte jednokrotnego i wielokrotnego wyboru z możliwością udzielenia własnej odpowiedzi. Metodyka badania została opisana w dalszej części artykułu.

Z przeprowadzonych badań wynika, iż o projekcie e-zdrowie nie słyszało $34,8 \%$ respondentów, natomiast $18,7 \%$ osób słyszało o nim, lecz nie wie, czego on dotyczy. Oznacza to, że ponad połowa osób (53,5\%) nie jest dostatecznie poinformowana, czym jest projekt e-zdrowie, oraz nie wie, jakie rozwiązania wdraża. Jest to niekorzystne zjawisko, ponieważ oznacza, że społeczeństwo nie jest świadome, czym jest e-zdrowie, a także jakie funkcjonalności z sobą niesie.

\section{Potencjał oraz zagrożenia związane z e-zdrowiem}

Termin ,e-zdrowie” jest stosunkowo nowy i po raz pierwszy został użyty w literaturze w roku 1998, natomiast do jego rozpowszechnienia przyczynił się Piąty Program Ramowy Badań, Rozwoju Technicznego i Prezentacji Unii Europejskiej (Komisja Europejska, 1999), realizowany w latach 1998-2002. Komisja Europejska zaproponowała jednak definicje tego terminu dopiero w roku 2003, sprowadzając e-zdrowie do zastosowania nowoczesnych technologii teleinformatycznych służących zaspokajaniu potrzeb pacjentów, obywateli, profesjonalistów ochrony zdrowia, dostawców świadczeń zdrowotnych i polityków. Uważa się, że e-zdrowie jest wspólną domeną obszaru ochrony zdrowia oraz sektora technologii teleinformatycznych, gdzie technologie informacyjno-komunikacyjne (ICT) mają na celu poprawę dostępności, efektywności oraz jakości świadczonych usług sektora ochrony zdrowia (Czerwińska, 2015, 345).

Praktyczny wymiar telemedycyny wyraża się dla przykładu w dostępie do informacji dotyczących zdrowia za pośrednictwem Internetu. Potencjalni pacjenci wykorzystują różne źródła informacji w celu lepszego zaspokojenia własnych potrzeb zdrowotnych, a fora i strony internetowe są coraz popularniejszym źródłem tych informacji. W 2013 roku w Polsce wśród osób w wieku 16-74 lata tylko $27 \%$ Polaków wykorzystywało Internet do wyszukiwania informacji zdrowot- 
nych (przy średniej w UE wynoszącej 44\%), natomiast w 2019 roku odsetek ten wynosił już 47\% przy średniej UE - 55\% (Eurostat, 2020).

Stosowanie nowych technologii w ramach publicznego systemu opieki zdrowotnej w całej Unii Europejskiej wydaje się nieuniknione. Fakt ten potwierdza Zielona księga w sprawie mobilnego zdrowia (Komisja Europejska, 2014). Stwierdza się w niej, że systemy opieki zdrowotnej w Unii Europejskiej stoją przed nowymi wyzwaniami, z którymi należy się zmierzyć. Należą do nich starzenie się społeczeństw oraz rosnąca presja budżetowa. W takim kontekście e-zdrowie może być jednym z narzędzi do sprostania tym wyzwaniom, przyczyniając się do skoncentrowanej w większym stopniu na pacjencie opieki zdrowotnej, oraz pozwoli wspierać przejście na profilaktykę, jednocześnie poprawiając wydajność całego systemu. Z jednej strony świadczy to o ogromnym potencjale innowacyjnego podejścia do ochrony zdrowia, $\mathrm{z}$ drugiej zaś o potrzebie rozważenia go w świetle bieżących zmian demograficznych współczesnych społeczeństw. Ponadto, zgodnie z tym dokumentem, rozwiązania w zakresie e-zdrowia mogą pomóc $\mathrm{w}$ wykryciu rozwoju chorób przewlekłych na wczesnym etapie za pomocą narzędzi do samooceny i zdalnej diagnozy, a udostępnianie tych danych usługodawcom ułatwiłoby terminową interwencję lekarza. e-zdrowie może przyczynić się również do skuteczniejszego sposobu świadczenia opieki zdrowotnej poprzez lepsze planowanie, ograniczenie niepotrzebnych konsultacji i lepiej przygotowanych specjalistów, otrzymujących wskazówki dotyczące leczenia. Rozwiązania w zakresie e-zdrowia sprzyjają zmianie roli pacjentów z biernej na bardziej partycypacyjną, zwiększając jednocześnie odpowiedzialność za własne zdrowie za pomocą aplikacji wykrywających i monitorujących objawy czynności życiowych, które zachęcają ich do przestrzegania diety i przyjmowania leków. Mogą także podnieść świadomość obywateli na temat problemów zdrowotnych i sposobu życia dzięki łatwym do zrozumienia informacjom o ich stanie zdrowia, pomagając w ten sposób podejmować bardziej świadome decyzje dotyczące zdrowia (Komisja Europejska, 2014). To wyraźnie pokazuje, że inicjatywy dotyczące e-zdrowia wpływają nie tylko na rozwiązania prawne, lecz także na ludzkie zachowanie i uczucia. Dlatego e-zdrowie oznacza wyzwanie zarówno dla prawników, jak i socjologów. Ponadto Amerykańskie Stowarzyszenie Telemedycyny wskazuje główne zalety stosowania nowoczesnych technologii w medycynie:

— stwarza nowe możliwości dla płatników, pacjentów i dostawców;

— daje polepszony dostęp do pacjenta;

— zwiększa zasięg usług opieki zdrowotnej;

— redukuje strukturę kosztów;

— umożliwia całodobową działalność;

— zapewnia większe zadowolenie beneficjentów (American Telemedicine Association, 2019). 
Niemniej jednak przy wdrażaniu nowoczesnych technologii mogą pojawić się pewne problemy z ich praktycznym zastosowaniem, co wydaje się naturalnym wynikiem zmiany istniejących rozwiązań. Należy się więc nastawić na:

— brak świadomości i zaufania do rozwiązań e-zdrowia wśród obywateli, pacjentów i pracowników służby zdrowia;

— ograniczoną liczbę badań na dużą skalę, potwierdzających efektywność kosztową narzędzi oraz usług e-zdrowia;

- nieodpowiednie albo fragmentaryczne ramy prawne, a także brak systemów refundacji usług e-zdrowia;

— wysokie koszty początkowe, które są powiązane z rozpoczęciem tworzenia systemów e-zdrowia;

— brak interoperacyjności między rozwiązaniami e-zdrowia;

— niepewność prawną odnośnie do aplikacji mobilnych dotyczących zdrowia oraz zdrowego stylu życia i brak przejrzystości w wykorzystywaniu danych gromadzonych przez takie aplikacje;

- regionalne różnice w dostępie do usług technologii ICT, ograniczony dostęp na obszarach ubogich (Komisja Europejska, 2012).

\section{E-pacjent}

Na gruncie e-zdrowia powstało pojęcie e-pacjenta. Pierwszy raz zostało ono użyte w 1996 roku przez Toma Fergusona. Jego koncept e-pacjenta jest rozwijany i wspierany w Stanach Zjednoczonych przez Society for Participatory Medicine (Towarzystwo Medycyny Partycypacyjnej). T. Ferguson w swoim dziele zdefiniował e-pacjenta jako konsumenta medycznego, który aktywnie uczestniczy w procesie dbania o swoje zdrowie, mającego do tego prawo i będącego do tego odpowiednio merytorycznie przygotowanym. Zgodnie z tą definicją e-pacjent jest aktywnym podmiotem uczestniczącym w wykonywaniu opieki zdrowotnej, a nie wyłącznie biernym przedmiotem różnych świadczeń zdrowotnych (Ferguson, 1996). Definicja ta nie odnosi się jednak do korzystania przez pacjentów z technologii ICT, a akcentuje wyłącznie ich aktywny udział w toku dbania o swoje zdrowie.

Współcześni badacze używają jednak określenia e-pacjent w takim kontekście, jak ma to miejsce przy definicji e-zdrowia. Dla przykładu Susannah Fox (2008) wiąże e-pacjentów z internautami, którzy poszukują w sieci informacji dotyczących zdrowia. Bardziej rozwinięta definicja e-pacjenta mówi, że jest to osoba, która bez względu na swój stan zdrowia wykorzystuje technologie komunikacyjno-informacyjne do świadczeń zdrowotnych. Jest to więc klasyczny pacjent, który zaopatrzony jest w nowoczesne technologie ICT. Obecnie nie istnieje żadna definicja e-pacjenta w aktach normatywnych. Warto jednak zauważyć, że pojęcie to podlega ciągłej ewolucji w kierunku m-pacjenta, a więc takiego, który korzysta 
z aplikacji mobilnych, i pacjenta inteligentnego, czynnie uczestniczącego w procesie dbania o swoje zdrowie, pozyskującego wiedzę medyczną, a także merytorycznie wspierającego personel medyczny. E-pacjent wykazuje e-zachowania, za które można uznać wszystkie możliwe do zaobserwowania w Internecie reakcje innych osób na bodźce pochodzące z otoczenia świata realnego lub rzeczywistości wirtualnej. E-pacjent może przejawiać zachowania bierne, a więc przeglądać strony internetowe $\mathrm{w}$ celu znalezienia istotnych dla siebie informacji, odbierać wyniki swoich badań lub e-maile. Może również zachowywać się aktywnie, to znaczy czynnie uczestniczyć w forach internetowych oraz wirtualnych społecznościach i umieszczać tam własne opinie oraz komentarze, prowadzić blog medyczny, korzystać z komunikatorów w celu kontaktu z lekarzem, robić zakupy internetowe czy korzystać ze zróżnicowanych usług zdrowotnych za pomocą Internetu (Jaciow, Wolny, 2011, 10).

\section{E-recepta}

W Polsce jest realizowany projekt Elektroniczna Platforma Gromadzenia, Analizy i Udostępniania Zasobów Cyfrowych o Zdarzeniach Medycznych (P1), dzięki któremu w ramach I etapu wdrożony został system informatyczny mający w założeniu usprawnić procesy związane z planowaniem oraz realizacją świadczeń zdrowotnych, monitorowanie i sprawozdawczość z ich realizacji, a także dostęp do informacji o udzielanych świadczeniach i publikowanie informacji w obszarze ochrony zdrowia, w zakresie zgodnym z ustawą o systemie informacji w ochronie zdrowia z dnia 28 kwietnia 2011 roku (Dz.U. z 2011 r. Nr 113, poz. 657).

Jednym z głównych celów P1 jest umożliwienie elektronicznej obsługi e-recept. Program pilotażowy e-recept w placówkach i aptekach w wybranych rejonach Polski rozpoczął się stosunkowo dawno - w maju 2018 roku, jednak dopiero od stycznia 2019 roku do systemu e-zdrowie włączono wszystkie apteki działające na terenie Polski. Od tej pory rozpoczęło się również włączanie do platformy e-zdrowie (P1) medycznych placówek i lekarzy (Centrum Systemów Informacyjnych Ochrony Zdrowia, 2020). Natomiast obowiązek wystawiania wyłącznie recept elektronicznych (z wyjątkiem przypadków określonych ustawowo) został wprowadzony dzięki zmianom w ustawie z dnia 19 lipca 2019 roku o zmianie niektórych ustaw w związku z wdrażaniem rozwiązań w obszarze e-zdrowia, na mocy której od 8 stycznia 2020 roku wprowadzony został obowiązek wystawiania recept $\mathrm{w}$ formie elektronicznej (Dz.U. z 2019 r. poz. 1590). Za korzyści wprowadzenia takiego rozwiązania z perspektywy pacjenta uznaje się rozwiązanie problemu nieczytelności papierowych recept, oszczędność czasu, podniesienie poziomu bezpieczeństwa przez ograniczenie prawdopodobieństwa wydawania niewłaściwego leku — innego niż ordynowany czy możliwość realizacji każdego leku w odrębnej aptece bez konieczności otrzymania ręcznego 
odpisu recepty. Dzięki wdrożeniu e-recepty polepszono warunki koordynacji procesu leczenia pacjentów przez udzielenie dostępu lekarzowi do wszystkich wystawionych pacjentowi recept, a także dokumentów ich realizacji (po wcześniejszym wyrażeniu zgody pacjenta). Pozwala to lekarzowi na ocenę i weryfikację realizacji recept przez pacjenta. W ramach funkcjonalności e-recepty lekarz ma również dostęp do listy refundowanych leków (Brożyna, Stach, Wróbel, 2019, 97).

Fundamentalną korzyścią, która wynika z wprowadzenia e-recepty w Polsce jest uproszczenie całościowego procesu realizacji recept. System P1 pełni funkcję repozytorium dla recept elektronicznych, dokumentów ich realizacji oraz anulowania. Podczas zapisywania tych dokumentów są one weryfikowane pod względem poprawności formalnej i technicznej. Dostęp do składowanych w systemie recept zależy od posiadanych uprawnień. Wystawienie oraz przesłanie do P1 elektronicznej formy recepty jest realizowane przez osobę będącą pracownikiem medycznym podmiotu, który wykonuje działalność leczniczą. Obowiązuje zasada umieszczania wyłącznie jednego produktu leczniczego na recepcie, przy jednoczesnej możliwości zapisania kilku recept. Wszystkie recepty skierowane do tego samego usługobiorcy, które są przekazywane do systemu P1 jako pojedynczy komunikat, zostają połączone w pakiet. Realizacja recept przebiega w taki sposób, że pacjent przekazuje pracownikowi apteki dane dostępowe — kod recepty oraz numer PESEL, co umożliwia pobranie recepty lub pakietu recept z systemu P1 w celu ich realizacji. Po wydaniu produktów leczniczych pracownik apteki przesyła dokument realizacji recepty do systemu P1. Pacjent przez portal Internetowe Konto Pacjenta (IKP) ma możliwość przeglądania wszystkich dokumentów elektronicznych przetwarzanych w systemie P1, między innymi recept oraz dokumentów ich realizacji (Brożyna et al., 2019, 97).

Doświadczenia krajów, które wdrożyły już system e-recept, wskazują, że zaimplementowanie systemu elektronicznej ordynacji leków zoptymalizowało czas pracy lekarza. Wdrożenie e-recepty w Szwecji pozwoliło zaoszczędzić lekarzowi do pół godziny dziennie. Istotną korzyścią jest także zmniejszenie kosztów w porównaniu do wystawienia recepty w formie papierowej (Deetjen, 2016, 7). Do 7 maja 2020 roku wystawiono w Polsce 209814349 e-recept, które zostały udzielone 21989916 pacjentom, co przekłada się na prawie 10 recept wystawionych na 1 pacjenta (NFZ, 2020).

\section{Opinie pacjentów korzystających z e-recept w świetle badania ankietowego}

Metoda badawcza zawarta w artykule opierała się na badaniach ankietowych z zastosowaniem techniki online. Było to podyktowane brakiem możliwości przeprowadzenia ankiet w formie face to face $\mathrm{z}$ powodu rozpoczynającej się pandemii COVID-19 i ograniczeniem działalności przychodni lekarskich, które miały być 
głównym miejscem przeprowadzania badań. $\mathrm{Z}$ racji tego badanie $\mathrm{w}$ formie kwestionariusza internetowego zostało zrealizowane przez platformę Google Forms. Celem ankiety było poznanie postaw, opinii oraz doświadczeń beneficjentów e-zdrowia dotyczących funkcjonowania omawianego projektu, zapoznanie się z przeszkodami, na jakie napotykają się pacjenci podczas korzystania z innowacyjnych rozwiązań e-zdrowia, uzyskanie informacji odnośnie do funkcjonalności, o które projekt mógłby zostać rozszerzony, a także poznanie opinii osób, którym projekt ten nie był wcześniej znany.

Kwestionariusz internetowy został przygotowany w taki sposób, aby umożliwiał zebranie odpowiedzi zarówno od osób, które spotkały się już wcześniej z zagadnieniami z zakresu e-zdrowia, jak i od tych, które nigdy o tym projekcie nie słyszały. Dla osób z grupy, która po raz pierwszy zetknęła się z e-zdrowiem, na początku każdej części ankiety przygotowane zostały szczegółowe wyjaśnienia dotyczące pojęć poruszanych w pytaniach. Badanie zostało przeprowadzone na terenie całego kraju na przełomie kwietnia i maja 2020 roku na próbie 305 osób. Istotne było, aby w badaniu wzięły udział nie tylko osoby młode, które - jak powszechnie się uważa — w łatwy i szybki sposób przyswajają nowości technologiczne, a poruszanie się po Internecie nie stanowi dla nich większego problemu, lecz także osoby starsze, dla których zmiana dotychczasowych przyzwyczajeń i postępująca digitalizacja życia może nastręczać kłopotów. W tym celu ankiety publikowane były między innymi na forach internetowych i w mediach społecznościowych zrzeszających osoby w wieku poprodukcyjnym, a więc osoby na emeryturze, rencie, zajmujące się wychowywaniem wnuków itp. Osoby w wieku $40+$ stanowiły $46,8 \%$ wszystkich ankietowanych.

Funkcjonowanie e-recept od maja 2018 roku oraz wystawienie ich w ilości przekraczającej 200 milionów sztuk skutkuje tym, że w przeprowadzonym badaniu ankietowym znaczna część respondentów $(87,3 \%)$ zna e-recepty w stopniu całkiem dobrym lub bardzo dobrym, a tylko $12,7 \%$ poniżej tego poziomu. Co więcej, aż 86,6\% respondentów korzystało z e-recept, a jedynie 13,4\% nigdy nie miało z nimi styczności. Spośród osób, którym zdarzyło się korzystać z e-recept, aż 92,6\% ocenia je w stopniu dobrym lub bardzo dobrym. Zdania na ich temat nie ma $5,7 \%$ osób, podczas gdy $1,7 \%$ ocenia je w stopniu złym lub bardzo złym.

W przeprowadzonym przez autora badaniu pierwotnym celem było poznanie opinii oraz doświadczeń pacjentów co do pojawienia się w Polsce e-recept, w związku z czym zawarto pytania odnoszące się do tej materii. Okazuje się, że istotnym aspektem w przypadku osób, które oceniają e-recepty źle lub bardzo źle, jest to, że ponad połowie osób $(55,6 \%)$ nie podoba się konieczność podawania numeru PESEL w celu realizacji e-recepty w aptece. Natomiast drugą przyczyną negatywnego odbioru e-recept przez osoby z nich korzystające jest kwestia przyzwyczajenia do tradycyjnych recept papierowych, na co wskazało 33,3\% respondentów. Można wyciągnąć z tego wnioski, że dla osób korzystających z e-recept niezmiernie ważne jest bezpieczeństwo danych osobowych i należałoby się zasta- 
nowić, czy obowiązek podawania numeru PESEL w chwili realizacji e-recepty jest niezbędny, czy też można zastąpić to inną, niewymagającą podawania wrażliwych danych osobowych metodą. Dodatkowo pacjenci są przyzwyczajeni do tradycyjnych papierowych recept, co stanowi mniejszą przeszkodę, ponieważ wydaje się, że do zmiany takiego stanowiska wystarczy lepszy proces informowania społeczeństwa, czym są e-recepty i w jaki sposób działają, co powinno przekonać pacjentów do nowocześniej formy recept.

Odpowiedzi osób korzystających z e-recept, które oceniają je w sposób dobry lub bardzo dobry, zostały przedstawione na wykresie 1. Jak widać, respondenci w największym stopniu doceniają fakt, że istnieje możliwość odebrania kolejnej e-recepty bez fizycznej wizyty w gabinecie lekarza (72,3\%). Jest to możliwe w przypadku choroby przewlekłej, wymagającej stałego przyjmowania leków, a także po konsultacji, na przykład telefonicznej, z lekarzem. Drugą najczęściej wskazywaną zaletą $(51,3 \%)$ jest stała obecność e-recepty w systemie, co w praktyce uniemożliwia jej zgubienie, jak było to możliwe w przypadku recept papierowych, które również w zdecydowanie łatwiejszy sposób ulegały zniszczeniu. Trzecią najczęściej wskazywaną przez respondentów odpowiedzią był brak problemu z odczytaniem pisma lekarskiego $(46,2 \%)$.

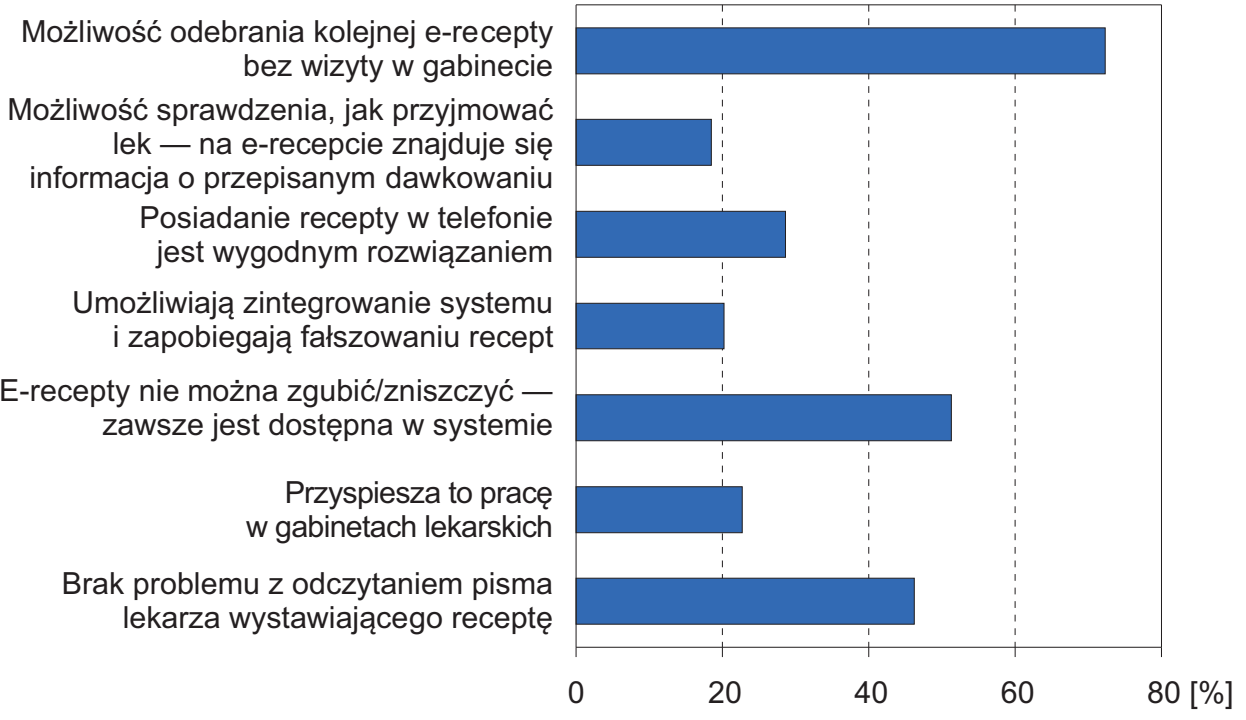

Wykres 1. Najważniejsze udogodnienia e-recept zdaniem korzystających z nich ankietowanych Źródło: opracowanie własne na podstawie przeprowadzonych badań.

Przechodząc do odpowiedzi osób, które nigdy nie słyszały o e-receptach bądź z nich nie korzystały, należy wskazać, że respondenci zostali poinformowani $\mathrm{w}$ ankiecie, czym są oraz $\mathrm{w}$ jaki sposób funkcjonują recepty elektroniczne. 
Badania wykazały, że aż 90,1\% respondentów jest skłonnych korzystać z e-recept zamiast tradycyjnych papierowych, natomiast tylko 4,4\% zdecydowanie wybiera formę tradycyjną.

Podobnie jak w przypadku osób korzystających z e-recept osoby niemające z nimi do czynienia w największym stopniu doceniają możliwość odebrania kolejnych e-recept bez wizyty u specjalisty (54,9\%). Drugą rzeczą, która najbardziej skłoniłaby takie osoby do korzystania z elektronicznych recept, jest brak problemu z odczytaniem pisma lekarskiego $(48,4 \%)$. Natomiast trzecią zachętą jest to, że e-recept nie można zgubić oraz zniszczyć, ponieważ zawsze są one dostępne w systemie. Warto zaznaczyć, że przy tym pytaniu pojawiały się liczne odpowiedzi, które chwaliły e-recepty za ich ekologiczną formę, do której nie zużywa się papieru (z wyjątkiem wydruku e-recepty). Biorąc pod uwagę, że zgodnie z § 9 ust. 1 rozporządzenia ministra zdrowia $z$ dnia 8 marca 2012 roku w sprawie recept lekarskich tradycyjne recepty papierowe nie mogły mieć wymiarów mniejszych niż 200 mm długości i 90 mm szerokości (Dz.U. z 2012 r. poz. 260) oraz że od maja 2018 roku do 7 maja 2020 roku wystawiono 209814349 e-recept, przez 2 lata można było zaoszczędzić około 3,8 ton papieru.

\section{Możliwość odebrania kolejnej e-recepty bez wizyty w gabinecie \\ Możliwość sprawdzenia, jak przyjmować lek - na e-recepcie znajduje się informacja o przepisanym dawkowaniu Posiadanie recepty w telefonie jest wygodnym rozwiązaniem \\ Umożliwiają zintegrowanie systemu i zapobiegają fałszowaniu recept \\ E-recepty nie można zgubić/zniszczyć - zawsze jest dostępna w systemie Przyspiesza to prace
w gabinetach lekarskich \\ Brak problemu z odczytaniem pisma lekarza wystawiającego receptę}

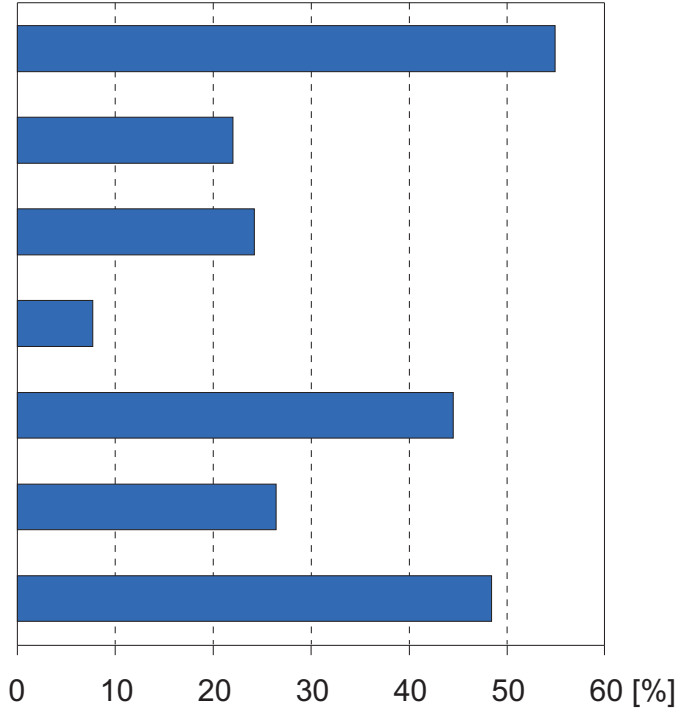

Wykres 2. Najważniejsze udogodnienia e-recept zdaniem respondentów, którzy z nich nie korzystali

Źródło: opracowanie własne na podstawie przeprowadzonych badan.

Osoby, które nigdy nie korzystały z e-recept, widzą największe niebezpieczeństwo w obowiązku podawania numeru PESEL w momencie realizacji e-recepty - ta odpowiedź została podana przez 46,2\% respondentów. Dodatkowo $18,1 \%$ osób wskazało na obawę odnośnie do bezpieczeństwa swoich danych oso- 
bowych - chodzi tutaj o potencjalne ryzyko wycieku danych z serwerów. Duża część osób uważa, że wypisywanie e-recept może wydłużyć czas wizyty lekarskiej — takiej odpowiedzi udzieliło 39\% badanych. Trzeci najczęściej wskazywany argument zniechęcający do korzystania z e-recept to kwestia przyzwyczajenia do tradycyjnych recept papierowych — taką odpowiedź zadeklarowało 35,7\% osób. Jest to pozytywna odpowiedź w takim sensie, że nasze przyzwyczajenia mogą ulegać zmianom w czasie i wraz z częstszym korzystaniem z nowych rozwiązań mogą stać się dla nas bardziej przyjazne i zrozumiałe.

\section{Internetowe Konto Pacjenta}

Jednym z głównych rozwiązań wdrażanych przy pomocy projektu e-zdrowie jest Internetowe Konto Pacjenta. Pierwsze profile można było zakładać od maja 2018 roku. Jest to narzędzie, które ma ułatwić pacjentom przyjazne korzystanie z cyfrowych usług oraz uporządkować rozproszone informacje medyczne dotyczące naszego zdrowia. Dostęp do Internetowego Konta Pacjenta jest możliwy przez rządową stronę internetową pacjent.gov.pl. Można znaleźć tam takie informacje, jak wszystkie wystawione i zrealizowane recepty od stycznia 2019 roku (w przypadku recept opłaconych przez Narodowy Fundusz Zdrowia — od 2008 roku) oraz dawkowanie przypisane przez lekarza, co pozwala zwiększyć bezpieczeństwo leczenia; przez portal można również uzyskać e-receptę na kontynuację leczenia bez obowiązku wizyty w gabinecie lekarskim, co pozwala zaoszczędzić czas. Znajdują się tam także takie informacje, jak historia wizyt w przychodniach zrealizowanych i sfinansowanych przez Narodowy Fundusz Zdrowia (NFZ) od 2008 roku, jak również koszt takich wizyt oraz wszelkich świadczeń opłacanych przez NFZ, co pozwala na zachowanie większego porządku w dokumentach medycznych - zgodnie z ustawą z dnia 28 kwietnia 2011 roku o systemie informacji w ochronie zdrowia (Dz.U. z 2011 r. Nr 113, poz. 657) za elektroniczną dokumentację medyczną uznaje się: dokument elektroniczny, który umożliwia usługobiorcy uzyskanie świadczenia opieki zdrowotnej danego rodzaju, w przypadku usługodawcy, który jest świadczeniodawcą — realizującym czynności z zakresu wyposażenia w środki pomocnicze oraz ortopedyczne wyroby medyczne; apteką ogólnodostępną lub punktem aptecznym, uznaje się dokumentację medyczną indywidualną, z wyłączeniem skierowań, a także dokumentację medyczną wytworzoną w postaci elektronicznej, która zawiera dane o udzielonych, udzielanych bądź planowanych świadczeniach opieki zdrowotnej, a także dokument elektroniczny, który umożliwia usługobiorcy uzyskanie świadczenia opieki zdrowotnej danego rodzaju. Dodatkowo portal ten może pomóc w opiece nad osobami starszymi, ponieważ w wypadku udzielenia przez nich dostępu dla bliskich rodzina opiekująca się starszymi osobami może kontrolować, czy przyjmują oni zaordynowane im leki (NFZ, 2020). 
Internetowe Konto Pacjenta to również korzyści dla lekarzy i farmaceutów. Przede wszystkim pacjent może udzielić danemu lekarzowi dostępu do swoich danych, co ułatwia monitorowanie przebiegu leczenia. Inną zaletą jest zwiększenie bezpieczeństwa - lekarz może kontrolować, jakie leki przyjmuje pacjent i czy są one przez niego wykupywane - według danych NFZ w Polsce aż $60 \%$ chorych nie wykupuje bowiem przypisanych im leków. Internetowe Konto Pacjenta jest też wsparciem w opiece farmaceutycznej, jako że istnieje możliwość nadania upoważnienia farmaceucie, aby ten miał wgląd do przypisywanych pacjentowi leków. W przypadku osoby przewlekle chorej farmaceuta może zrobić przegląd przyjmowanych przez niego leków oraz przepisać kolejne w ramach kontynuacji zleconego leczenia przez lekarza (NFZ, 2019).

Jak się jednak okazuje, 48,8\% respondentów badania ankietowego określa znajomość Internetowego Konta Pacjenta w stopniu całkiem dobrym lub bardzo dobrym, a $27,6 \%$ zna portal tylko trochę, natomiast $23,6 \%$ osób nigdy nie słyszało o Internetowym Koncie Pacjenta bądź nie ma pojęcia, czego on dotyczy. Jeszcze gorzej wyglądają dane dotyczące korzystania z portalu, ponieważ 42,3\% osób nigdy z niego nie korzystało. Pozytywnie należy jednak ocenić fakt, że wśród osób, które korzystały z Internetowego Konta Pacjenta, aż 84,5\% ocenia go w stopniu dobrym lub bardzo dobrym, $14,1 \%$ nie ma zdania na jego temat, a tylko $1,4 \%$ ocenia portal źle lub bardzo źle.

Niezaprzeczalnie najważniejszym udogodnieniem wprowadzonym przy pomocy Internetowego Konta Pacjenta jest dostęp do zrealizowanych i wystawionych recept — taką odpowiedź wskazało aż $90,1 \%$ ankietowanych. Ponad połowa osób $(67,6 \%)$ docenia dostęp do zaplanowanych i historycznych wizyt lekarskich; trzecią najczęściej wybieraną opcją - 46,5\% — był dostęp do e-skierowań.

Niepokojące odpowiedzi osób korzystających z Internetowego Konta Pacjenta na pytanie, co stanowi największą przeszkodzę w korzystaniu z portalu, zostały przedstawione na wykresie 3. Większość osób $(57,7 \%)$ podała, że prezentowane na portalu dane są niekompletne lub sprzeczne z faktycznym stanem rzeczy. Sam osobiście korzystając z portalu, napotkałem na moim profilu błędne dane dotyczące historii leczenia - były tam zapisane wizyty, które nigdy się nie odbyły, oraz brakowało niektórych wystawionych i zrealizowanych recept. Dodatkowo 26,8\% respondentów wskazało na brak płynności w funkcjonowaniu strony oraz długi czas ładowania danych. Jedynie $22,5 \%$ osób jest zdania, że Internetowe Konto Pacjenta nie ma wad. Takie wyniki oznaczają, że przed Ministerstwem Zdrowia, które odpowiedzialne jest za portal, jeszcze dużo pracy — należy skupić się na zapewnieniu kompletu rzetelnych danych każdego pacjenta, wyeliminować dane niezgodne z prawdą oraz popracować nad płynnością działania całego serwisu.

Przechodząc do odpowiedzi osób, które nigdy nie korzystały z Internetowego Konta Pacjenta, należy wspomnieć, że podobnie jak w przypadku e-recept zostały one poinformowane, czym jest Internetowe Konto Pacjenta oraz jakie funkcjonalności z sobą niesie. Za pozytywny należy uznać fakt, że 80,3\% respondentów 


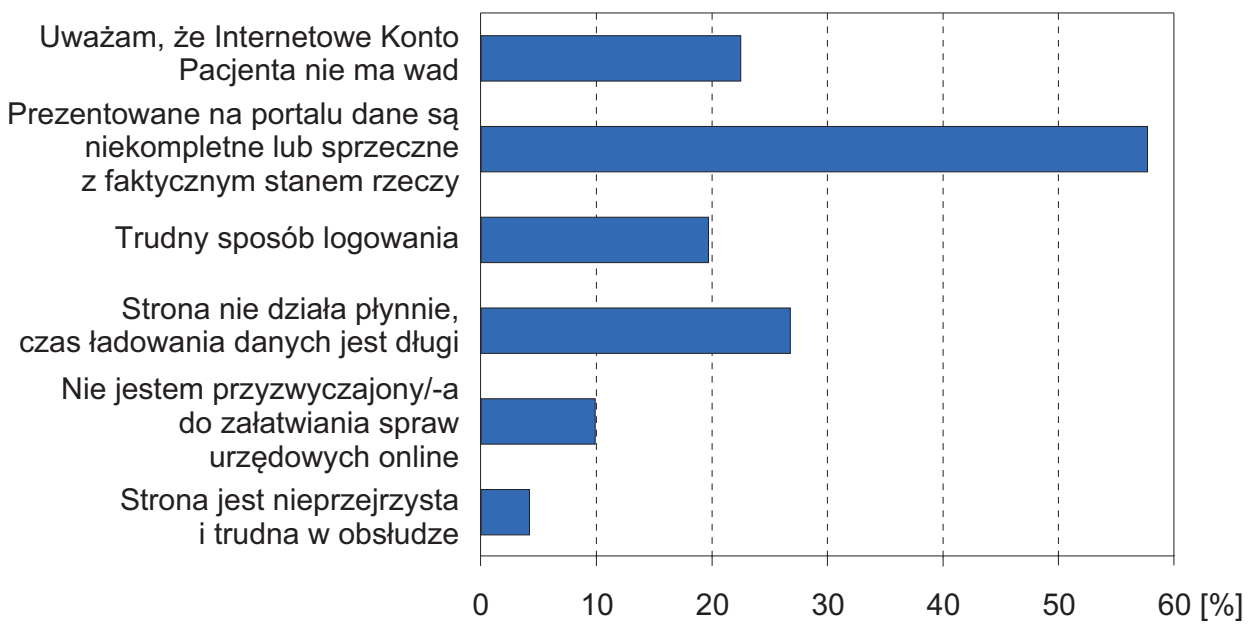

Wykres 3. Największe przeszkody w korzystaniu z Internetowego Konta Pacjenta zdaniem użytkowników

Źródło: opracowanie własne na podstawie przeprowadzonych badań.

wyraziło chęć korzystania z portalu, $7,7 \%$ jest niezdecydowanych, a tylko $12 \%$ stwierdziło, że prawdopodobnie bądź z całą pewnością nie skorzysta z tego serwisu. Jak się okazuje, wśród osób, które nigdy nie korzystały z Internetowego Konta Pacjenta, podobnie jak w przypadku osób z niego korzystających, pierwszymi trzema udogodnieniami zachęcającymi do korzystania jest dostęp do wystawionych i zrealizowanych recept $(58,5 \%)$, zaplanowanych i historycznych wizyt lekarskich $(49,6 \%)$ oraz e-skierowań $(41,5 \%)$.

Inaczej natomiast wyglądają odpowiedzi dotyczące największych przeszkód w korzystaniu z Internetowego Konta Pacjenta, które zostały przedstawione na wykresie 4 . Ponad połowa respondentów $(54,3 \%)$ wskazała na trudny sposób logowania do portalu. Warto w tym miejscu napisać więcej słów na ten temat.

Pierwszym ze sposobów logowania jest profil zaufany. Jest to bezpłatny sposób potwierdzenia swojej tożsamości w systemach administracji elektronicznej. Działa on jak odręczny podpis. Można dzięki niemu wysłać przez Internet wnioski i dokumenty do różnych urzędów, a także zalogować się do Internetowego Konta Pacjenta. Jest to względnie bezpieczna metoda, ponieważ nikt poza właścicielem nie może z niej skorzystać. Profil zaufany można założyć na dwa sposoby. Pierwszy z nich jest możliwy poprzez stronę online - z wykorzystaniem bankowości elektronicznej. Wystarczy zalogować się na swoje konto bankowe i wypełnić stosowny formularz zakładania profilu zaufanego (warto jednak nadmienić, że obecnie jeszcze nie każdy bank działający w Polsce udostępnia taką możliwość). Drugi ze sposobów wymaga wypełnienia formularza rejestracyjnego na stronie pz.gov.pl lub ePUAP, a następnie osobistego stawienia się w punkcie potwierdza- 
jącym, na przykład w urzędzie gminy, urzędzie skarbowym czy oddziale NFZ, w celu potwierdzenia swojej tożsamości (NFZ, 2020).

Drugą możliwością zalogowania do Internetowego Konta Pacjenta jest posiadanie e-dowodu. Przede wszystkim należy do tego posiadać dowód wydany po 4 marca 2019 roku, który ma warstwę elektroniczną, dodatkowo należy pobrać na swój komputer oprogramowanie do obsługi e-dowodów oraz zaopatrzyć się w czytnik NFC i podłączyć go do komputera. Po umieszczeniu e-dowodu na czytniku wymagane jest podanie numeru CAN (sześciocyfrowy numer nadrukowany na awersie dowodu osobistego), a następnie czterocyfrowego numeru PIN, który został przez nas ustalony przy odbiorze dowodu (Ministerstwo Cyfryzacji, 2020). Dopiero wtedy występuje prawidłowe zalogowanie się do Internetowego Konta Pacjenta.

Jak możemy zauważyć, obie metody logowania do portalu nie należą do najłatwiejszych — pierwszy sposób wymaga korzystania z bankowości mobilnej i jest ograniczony do wybranych banków w Polsce, natomiast do korzystania z drugiej metody należy posiadać dowód osobisty z warstwą elektroniczną, specjalne oprogramowanie komputerowe oraz czytnik NFC. Biorąc to pod uwagę, zrozumiałe jest, że dla ponad połowy badanych sposób logowania jest największą przeszkodą korzystania z Internetowego Konta Pacjenta. Dodatkowo trudny sposób logowania może przekładać się na małą liczbę założonych kont, ponieważ do dnia 10 maja 2020 roku z Internetowego Konta Pacjenta skorzystało tylko 2275562 pacjentów (NFZ, 2020).

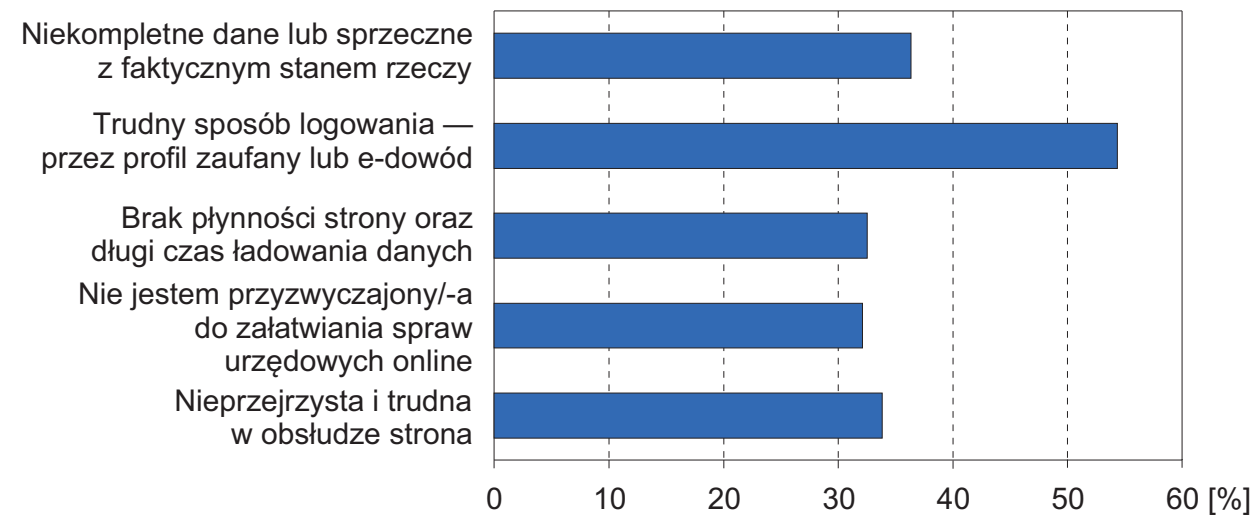

Wykres 4. Największe przeszkody w rozpoczęciu korzystania z Internetowego Konta Pacjenta zdaniem ankietowanych

Źródło: opracowanie własne na podstawie przeprowadzonych badań.

Celem badania ankietowego było również zbadanie zainteresowania rozszerzeniem programu e-zdrowie. Jak się okazuje, tylko 4,9\% osób uważa, że wszystko, co niezbędne, zostało już wprowadzone. Nową usługą, którą najchętniej wi- 
dzieliby ankietowani, jest dostęp online do wyników badań (71,8\% wskazań), kolejnym najczęściej wskazywanym udogodnieniem jest rejestracja online do każdej przychodni $(52,1 \%)$, na trzecim miejscu znalazła się wyszukiwarka aptek, w których dostępny jest nasz lek (41\%). Wydaje się, że nic nie stoi na przeszkodzie, aby do funkcjonalności Internetowego Konta Pacjenta dodać wyniki badań online, przynajmniej tych finansowanych i realizowanych przez NFZ, zwłaszcza że wiele prywatnych firm diagnostycznych umożliwia taką usługę od wielu lat. Wydaje się również, że w ramach procesu cyfryzacji służby zdrowia możliwe byłoby wprowadzenie rejestracji online do każdej przychodni, a także wyszukiwarki aptek, w której dostępny jest nasz lek. Udogodnienia tego typu mogłyby się przyczynić do zwiększenia liczby osób korzystających z usług e-zdrowia i do ogólnego polepszenia odbioru całego systemu.

Jednak pomimo licznych głosów, że program e-zdrowie należy rozszerzyć, aż 72,4\% osób uważa, że system e-zdrowie wpłynął pozytywnie na jakość usług świadczonych przez polską służbę zdrowia, $23 \%$ osób jest zdania, że system ten nie wywarł znaczącego wpływu, natomiast jedynie $4,6 \%$ respondentów uznaje, że wywarł on negatywny wpływ. Jednocześnie $47,5 \%$ respondentów twierdzi, że system e-zdrowie ułatwił pracę lekarzom dzięki zintegrowanemu systemowi, który pozwala na sprawdzenie historii wizyt pacjenta czy branych przez niego leków, co wpływa na skrócenie czasu wizyty; odmiennego zdania jest 30,2\% badanych. Głównym argumentem osób, które uważają, że e-zdrowie utrudnia pracę lekarzom, jest nieprzystosowanie przychodni do pracy z wykorzystaniem systemów informatycznych oraz pogląd, że wielu lekarzy nie radzi sobie z obsługą systemu, a nawet komputera, przez co czas wizyty ulega wydłużeniu.

\section{Podsumowanie}

Drugą dekadę XXI wieku charakteryzuje rozwój telemedycyny i e-zdrowia w Polsce. Przeprowadzone badanie wykazało jednak, że wiedza Polaków o projekcie e-zdrowie jest na stosunkowo niskim poziomie, a ponad połowa osób nie jest świadoma, czego on dotyczy. Pozytywnym aspektem jest natomiast to, że przechodząc do poszczególnych części składowych systemu e-zdrowie, znajomość usług typu e-recepty czy Internetowe Konto Pacjenta jest na zadowalająco wysokim poziomie. Należy jednak dążyć do intensyfikacji działań podnoszących świadomość pacjentów i przyszłych pacjentów na temat e-zdrowia, rozbudzić chęć korzystania $\mathrm{z}$ takich usług, a także informować o praktycznych korzyściach wynikających z funkcjonowania e-zdrowia.

Wyniki badań pozwoliły również potwierdzić postawioną na początku artykułu hipotezę, że wdrożenie projektu e-zdrowie zostało pozytywnie przyjęte przez beneficjentów. Okazuje się, że projekt e-zdrowie jest w znacznej mierze postrzegany przychylnie, pacjenci są skłonni korzystać z elektronicznych form 
dokumentacji medycznej, jak również pozytywnie oceniają poszczególne funkcjonalności sytemu.

Wydaje się, że wdrażaniu rozwiązań z zakresu e-zdrowia powinna towarzyszyć refleksja dotycząca poprawności wprowadzanych danych, a także prawidłowości funkcjonowania poszczególnych usług, aby zapewnić sprawne, pozbawione błędów działanie. Zdaniem respondentów to właśnie niekompletne i nieprawdziwe dane prezentowane w systemie teleinformatycznym e-zdrowie stanowią główną przeszkodzę w korzystaniu $\mathrm{z}$ tego typu usług oraz powodują, że system, który jest obarczony wadami, przestaje być atrakcyjny z punktu widzenia pacjentów, ale i lekarzy. Ministerstwo Zdrowia powinno zastanowić się również nad rozszerzeniem e-zdrowia o kolejne usługi, które przyciągnęłyby do projektu nowych pacjentów i pozwoliłyby na zwiększenie i tak już bardzo dobrego ogólnego odbioru systemu e-zdrowie.

\section{Bibliografia}

American Telemedicine Association. (2019). Data dostępu: 26.03.2020, http://www.americantelemed.org/about/about- telemedicine.

Brożyna, M., Stach, S., Wróbel, Z. (2019). Rozwój telemedycyny w Polsce po wdrożeniu Elektronicznej platformy gromadzenia, analizy i udostępniania zasobów cyfrowych o zdarzeniach medycznych (P1). W I. Lipowicz (red.), Telemedycyna i e-zdrowie (89-104). Warszawa: Wolters Kluwer.

Centrum Systemów Informacyjnych Ochrony Zdrowia (2020). Data dostępu: 18.01.2020, https:// www.csioz.gov.pl/projekty/realizowane/projekt-p1/.

Czerwińska, M. (2015). Specyfika zachowań e-pacjentów w Internecie. Roczniki Kolegium Analiz Ekonomicznych, 38, 343-351.

Deetjen, U. (2016). European E-Prescriptions: Benefits and Success Factors. Oxford: University of Oxford.

Eurostat. (2020). Individuals using the internet for seeking health-related information. Data dostępu: 17.01.2020, https://ec.europa.eu/eurostat/web/products-datasets/-/tin00101.

Ferguson, T. (1996). Health Online: How to Find Health Information, Support Groups, and Self-Help Communities in Cyberspace. Reading, MA: Da Capo Lifelong Books.

Fox, S. (2008). The engaged e-patient population. Pew Internet \& American Life Project. Washington. Data dostępu: 23.03.2020, http://www.pewinternet.org/files/oldmedia/Files/Reports/2008/ PIP_Health_Aug08.pdf.

Jaciow, M., Wolny, R. (2011). Polski e-konsument. Typologia, zachowania. Gliwice: Wydawnictwo Helion.

Komisja Europejska. (1999). FP5 — Fifth RTD Framework Programme, 1998-2002. Data dostępu: 17.01.2020, https://cordis.europa.eu/programme/id/FP5.

Komisja Europejska. (2012). Komunikat Komisji do Parlamentu Europejskiego, Rady, Europejskiego Komitetu Ekonomiczno-społecznego i Komitetu Regionów, plan działania w dziedzinie e-zdrowia na lata 2012-2020 - innowacyjna opieka zdrowotna w XXI wieku. Bruksela. Data dostępu: 26.03.2020, https://eur-lex.europa.eu/legal-content/p1/ALL/?uri=CELEX:52012DC0736.

Komisja Europejska. (2014). Zielona księga w sprawie mobilnego zdrowia (,,mHealth”). Bruksela. Data dostępu: 26.03.2020, https://ec.europa.eu/transparency/regdoc/rep/1/2014/PL/1-2014219-PL-F1-1.Pdf.

Ministerstwo Cyfryzacji. (2020). Data dostępu: 8.05.2020, https://www.gov.pl/web/e-dowod. 
NFZ. (2020). Data dostępu: 7.05.2020, http://www.nfz-opole.pl/gfx/nfz-opole/userfiles/_public/erecepty/e-zdrowie przewodnik_od_a_do_z_www-final_25.09.2019.pdf.

NFZ. (2020). Data dostępu: 7.05.2020, https://ezdrowie.gov.p1/.

NFZ. (2020). Data dostępu: 7.05.2020, https://pacjent.gov.pl/.

NFZ. (2020). Data dostępu: 8.05.2020, https://pz.gov.pl/Instrukcja_Uzytkownika_PZ.pdf.

Rozporządzenie Ministra Zdrowia z dnia 8 marca 2012 roku w sprawie recept lekarskich, Dz.U. z 2012 r. poz. 260.

Ustawa z dnia 28 kwietnia 2011 roku o systemie informacji w ochronie zdrowia, Dz.U. z 2011 r. $\mathrm{Nr} 113$, poz. 657.

Ustawa z dnia 19 lipca 2019 roku o zmianie niektórych ustaw w związku z wdrażaniem rozwiązań w obszarze e-zdrowia, Dz.U. z 2019 r. poz. 1590. 